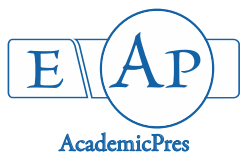

Olokeogun OS et al. (2020)

Notulae Scientia Biologicae 12(4):959-971

DOI: $10.15835 / 12410808$

Research Article

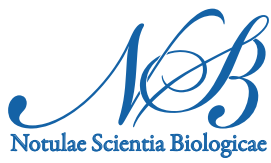

\title{
Geospatial analysis-based approach for assessing urban forests under the influence of different human settlement extents in Ibadan city, Nigeria
}

\author{
Oluwayemisi S. OLOKEOGUN ${ }^{1 *}$, Abiodun O. OLADOYE ${ }^{2}$, \\ Oluwatoyin O. AKINTOLA ${ }^{1}$
}

\author{
${ }^{1}$ Federal College of Forestry, Department of Forestry Technology, P.M.B. 5054, Ibadan, Oyo State, \\ Nigeria; olokeogunoluwayemisi@gmail.com (*correspondingauthor); toyinakintola73@gmail.com \\ ${ }^{2}$ Federal University of Agriculture, Department of Forestry and Wildlife Management, Abeokuta, Nigeria; segun11us@yahoo.com
}

\begin{abstract}
Urban forests are an essential component of urban areas as they provide many environmental and social services that contribute to the quality of life in cities. Urban forests in most cities of Nigeria are gradually becoming bitty as a result of urbanization activities, thereby posing adverse effects. In this study, we assessed the changes in the urban forests cover under the influence of different human settlement (HS) extents across the urban area of Ibadan city using remotely sensed data. The pattern of change(s) in the urban forests cover over 20 years were examined by analysing and manipulating Landsat and Sentinel-2 datasets using Google Earth Engine, ArcGIS 10.1, and Erdas 2014 software. The extents of human settlement (for the year 2000, 2005, 2010, 2015, and 2020) were extracted (from Landsat datasets), analysed, and mapped to evaluate the status of the urban forests cover under different human settlement extents. The result reveals a substantial land cover changes within the urban area of Ibadan. The urban forest cover decreased from $24.14 \%$ to $7.99 \%$. Also, there is a significant decrease in the urban forests cover as a result of a substantial increase in human settlement extent (102,806 to 122,572 pixels). The study provides an opportunity to map the status of urban forest cover and extents of HS in a developing city using remotely sensed data and applications of GIS tools.
\end{abstract}

Keywords: GIS; human settlement; remote sensing; remotely sensed data; urban forests

\section{Introduction}

Urban forests are ecosystems characterized by the presence of trees and other vegetation in association with the people and their developments (Nowak et al., 2001; Adelusi et al., 2002). They are also considered as the sum of all woody and associated vegetation in and around dense human settlements from small communities to large metropolitan cities (Gann, 2003). According to Clark et al. (1997), a sustainable urban forest is defined as the naturally occurring and planted trees in cities, managed to provide the inhabitants with a continuing level of economic, social, environmental, and ecological benefits today and into the future. Comprehensively, urban forests are viewed as trees on the land that fulfil the requirements of forest and other wooded lands except that the area is less than 0.5 ha (Larinde, 2010). 
Urban forest significantly influences the sustainability and environmental quality of a city. A large, healthy urban forest can increase local urban air quality and mitigate carbon dioxide emissions (McPherson and Rowntree, 2016; Nowak et al., 2007); decrease temperature elevated by the urban heat island (UHI) effect and decrease associated energy costs (McPherson and Simpson, 2001); increase city walkability (Wolf, 2008); provide stormwater retention services including decreased peak flow and increased water quality (McPherson, 2006); contribute to economic prosperity through increased job opportunities and increased retail sales in urban areas with trees (Wolf, 2005a, 2005b); as well as many other benefits that increase the overall quality of the urban environment and the quality of life for urban residents (McPherson, 2006).

Recently, urban forests within Ibadan city are gradually becoming more fragmented due to urbanization causing ripple effects such as the expansion of human settlement, increased infrastructural development, change in the city's landscape pattern, and design. The impact of their continuing disappearance is manifested through increased UHI effect, changes in microclimate, and rainfall pattern. Also, the city lacks proper and comprehensive knowledge of the status and performance of its urban forests thereby making it difficult to preserve and enhance it. Therefore, there is a need for an evaluation of these urban forests. We assess here the changes in the landscape pattern occurring over assessment years as it relates to the extents of human settlement.

Assessment of changes in the landscape pattern using remotely sensed data and geographic information system (GIS) help to depict, quantify, and map, among other factors, the change in landform (on a large scale) from permeable to impermeable surfaces with urban development (Booth et al., 1989; Booth, 1990; Masek et al., 2000; Klemas, 2001; Hayden, 2004; Lunetta et al., 2004; Kulash, 2009; Tan et al., 2010; Banai and DePriest, 2014; Chen and Guinness, 2014; Kumar et al., 2019; Savita et al., 2019). Urban forest managers and city planners require this information to direct future patterns of growth and green space development and also to prepare an effective and efficient urban forest management plan.

How degraded are these urban forests as a result of urbanization (in terms of human settlement extent) pressure is one of the key questions for forest policymakers and city planners? To address this question, here we assess the impact of the trend in human settlement spatial extent on urban forests cover across the urban area of Ibadan city in the south-west region of Nigeria using remotely sensed data. We focused more on the exploitation of Landsat data potentials in assessing urban forest cover and also in extracting consistent human settlement extent layers at a $30 \mathrm{~m}$ spatial posting and time series. The specific objectives of the study are to (1) delineate and classify the urban forests using Landsat and Sentinel datasets to understand the pattern of change over 20 years (at an interval of 5 years) and; (2) extract human settlement extent from Landsat data (at an interval of 5 years, for 20 years) and evaluate the status of the urban forests under different human settlement extents.

\section{Materials and Methods}

\section{Study area}

The study was conducted in the urban area of Ibadan city, an ancient city of the Nigerian western region that has witnessed rapid urbanization in the recent past era. Ibadan is the capital city of Oyo state in Nigeria having it extent between latitude $7^{\circ} 2^{\prime} \mathrm{N}-7^{\circ} 44^{\prime} \mathrm{N}$ and longitudes longitude $3^{\circ} 30^{\prime} \mathrm{E}-4^{\circ} 9^{\prime} \mathrm{E}$ (Figure 1). It is located at a distance of about $120 \mathrm{~km}$ East of the border with the Republic of Benin in the forest zone, close to the boundary between the forest and the Savanna. The city is naturally drained by four rivers (Ona river, Ogbere river, Kudeti river, and Ogunpa river) with many tributaries: It covers an area of 3,080 sq. $\mathrm{km}$.

The elevation of the city ranges from $150 \mathrm{~m}-275 \mathrm{~m}$ above sea level. The climate of the city is a tropical wet and dry climate with a lengthy wet season and relatively constant temperatures throughout the year. The wet season runs from March through October, though August seems somewhat of a lull in precipitation, while November to February forms the city's dry season, during which it experiences the typical West African 
harmattan. It receives a mean total rainfall of $1420.06 \mathrm{~mm}$, falling in approximately 109 days. There are two peaks for rainfall, June and September. The mean minimum and maximum temperatures are $21.42{ }^{\circ} \mathrm{C}$ and $26.46^{\circ} \mathrm{C}$, while the relative humidity is $74.55 \%$.

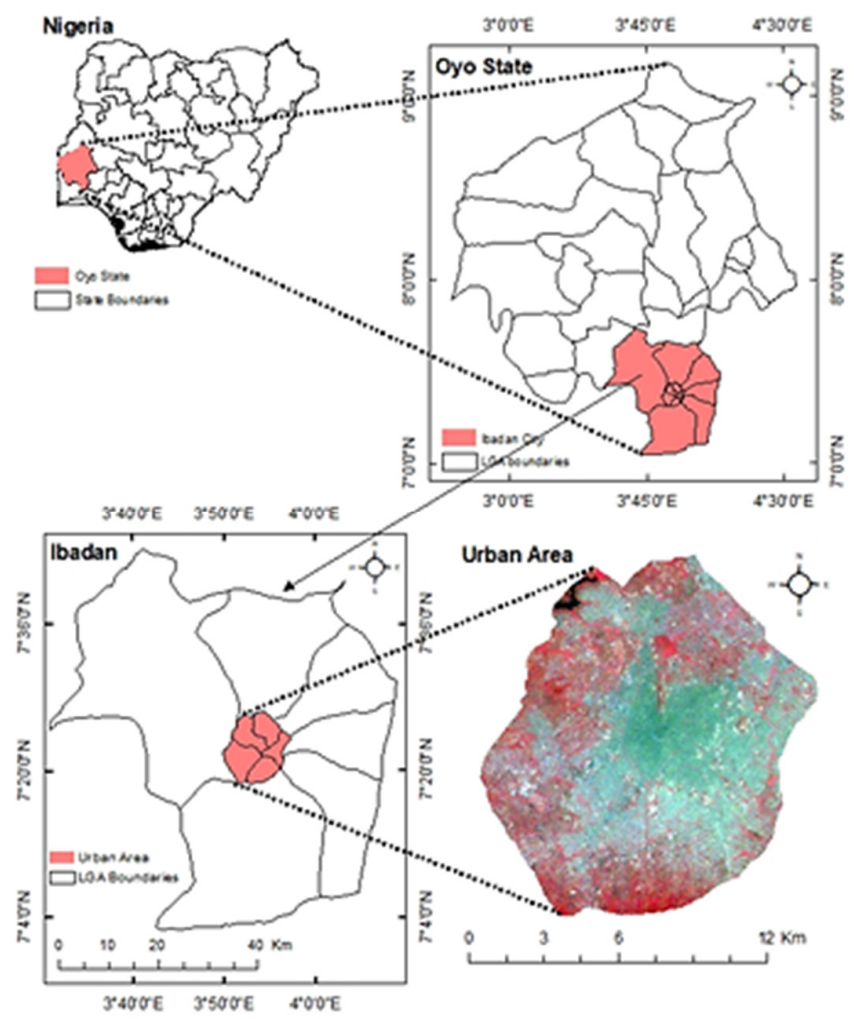

Figure 1. Location map of the study area, Urban area of Ibadan (showing a satellite image) in Oyo State, Nigeria

Geologically, the study area lies within the basement complex rocks of metamorphic origin of the Precambrian age (Figure 2). The rocks are divided into two groups; quartzite of the meta-sedimentary series and the migmatite complex consisting of banded gneiss, augen gneiss and magnetite; and other ones include pegmatite, quartz, aplite, diorite, amphibolites and zenoliths (Amanambu, 2015). The rock types are a major factor controlling the characteristics of the groundwater resource in the study area. Basement complex rocks (consisting of metamorphic and igneous rock types) are fairly low in groundwater yield when compared with sedimentary rock areas to the south

lbadan urban area (Figure 3) had four forest reserves (Popoola and Ajewole, 2001). Alalubosa forest reserve (constituted in 1916), a land area of 308.53 ha destroyed and converted to residential quarters and 'Aiesinloye' market. On the other hand, Oke Aremo reserve (constituted in 1935) with a total land area of $57.67 \mathrm{ha}$, also de-reserved with greater part ceded for the development of the new King's (Olubadan) palace and associated projects. Ogunpa dam forest reserve (constituted in 1931, but later declared a game reserve in 1952) over an area of $81.27 \mathrm{ha}$, also destroyed and larger portion of it has given way for the construction of the cultural center, Premier hotel, and public schools. Eleyele forest reserve (acquired in 1941 and formally constituted a reserve in 1956) with an area of $325.2 \mathrm{ha}$, is gradually been converted into a residential area. 


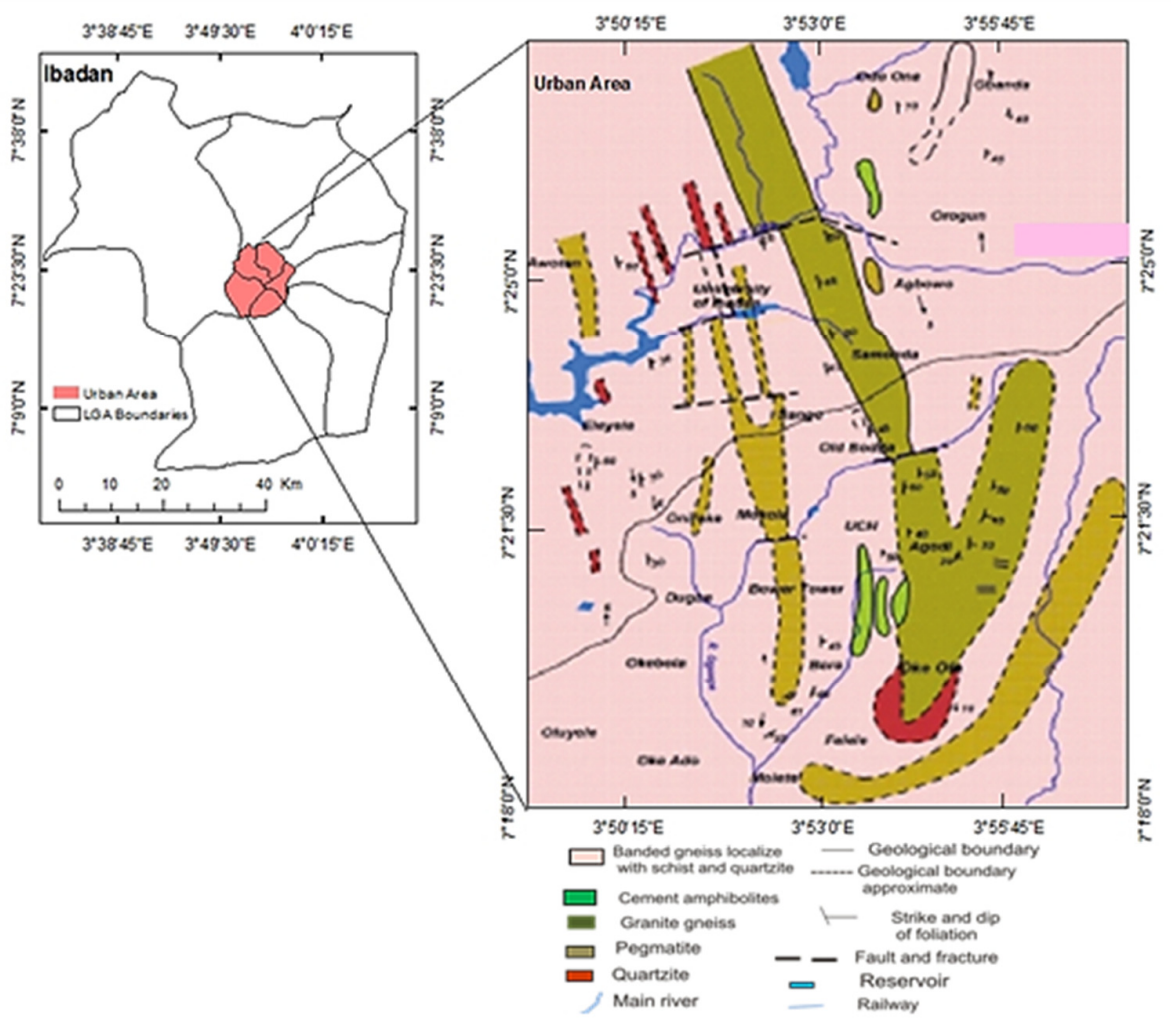

Figure 2. Geological map of the urban area of Ibadan (After Amanambu, 2015)

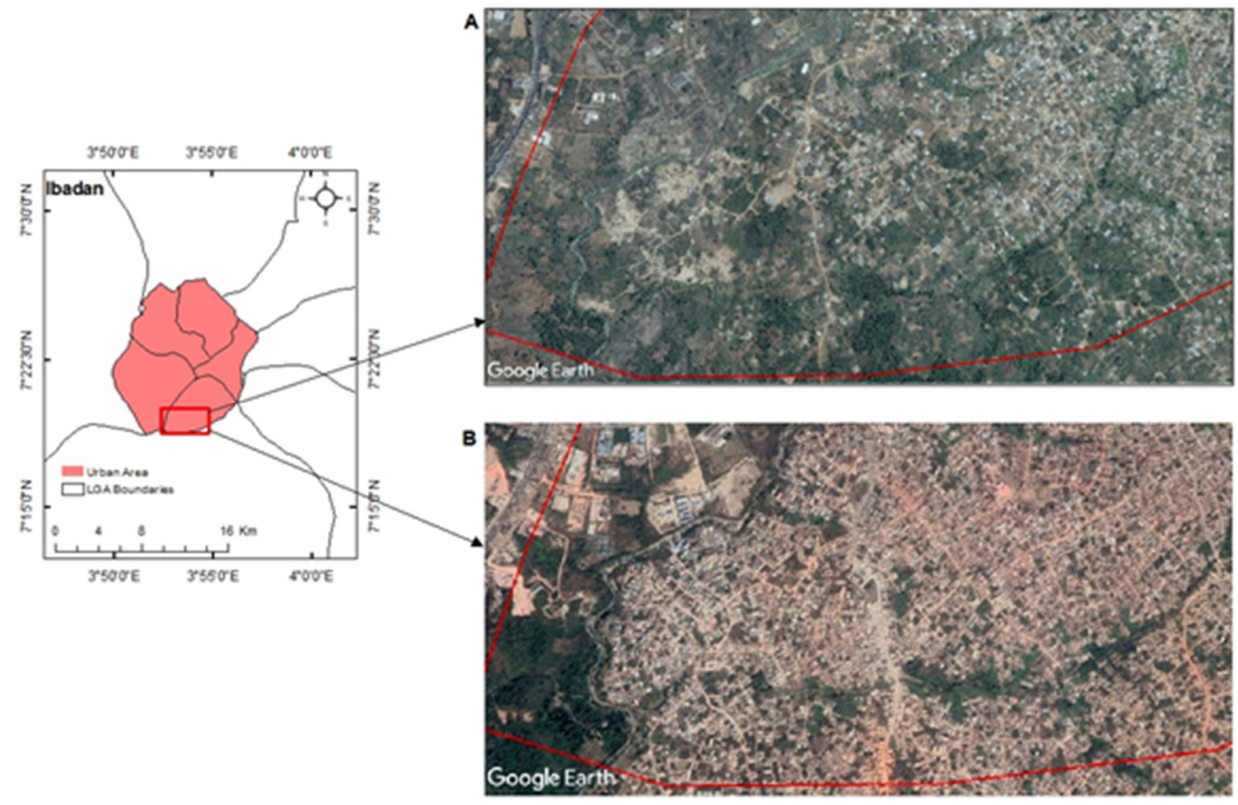

Figure 3. Map of urban area of Ibadan (showing a satellite image covering Challenge/Olomi Area), Nigeria: (a) year 2000; (b) year 2020 
Data source and analytical tools used

In this study, remotely sensed data (satellite images) were primarily used. Multispectral satellites (Landsat-5, $7 \&$ \& , and Sentinel-2) datasets were extracted using Google Earth Engine (GEE). The GEE (https://earthengine.google.com/) provides planetary-scale geospatial analysis through large scale cloud computing to extract various archived geospatial layers to perform scientific analysis (Gorelick et al., 2017; olokeogun and Kumar 2020). The manipulation, processing, and handling of the remotely sensed data involved the use of GEE, ArcGIS and ERDAS EMAGINE software as shown in Figure 4.

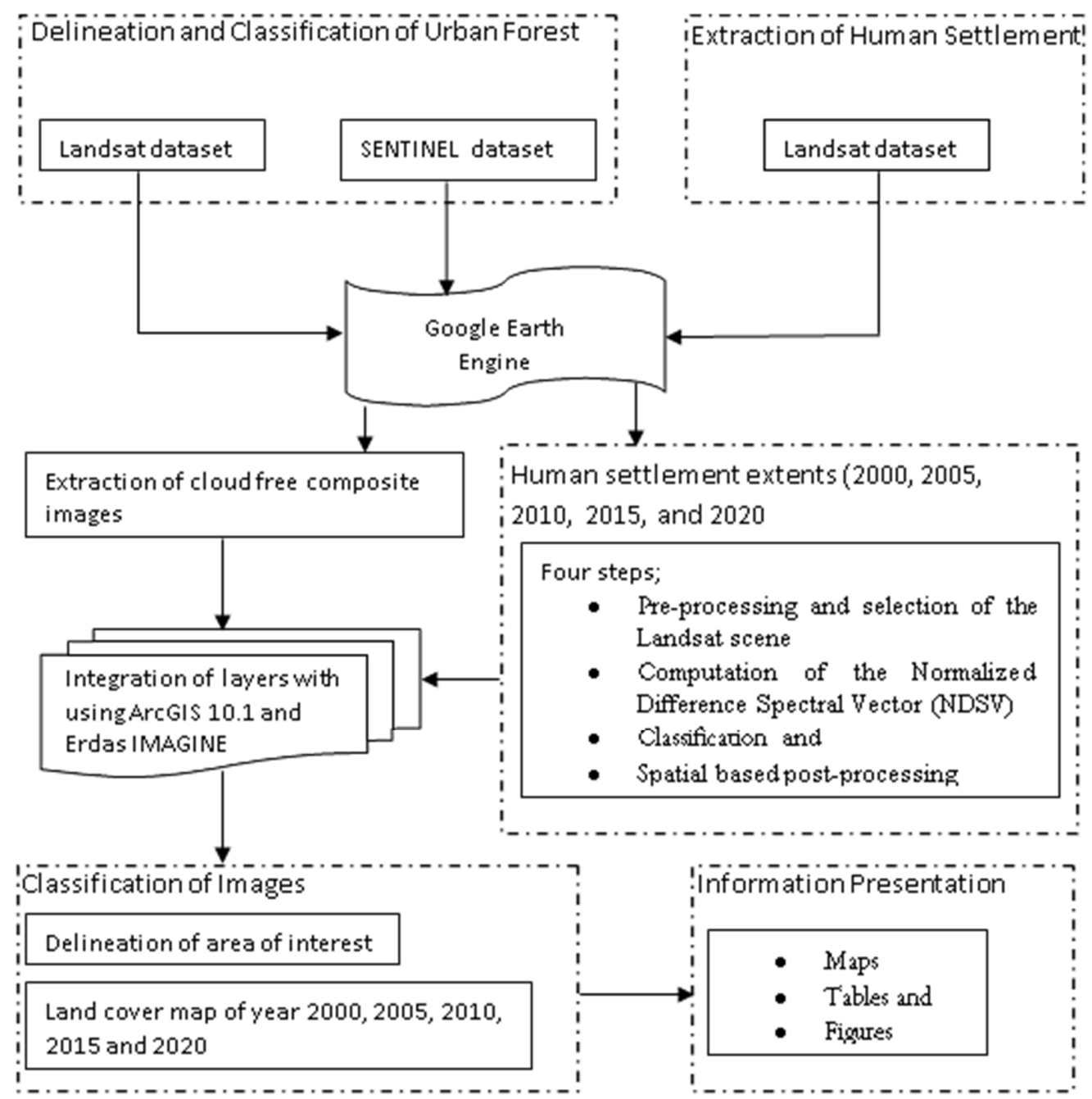

Figure 4. Schematic representation of steps involved in the study

\section{Delineation and classification of the urban forest using remotely sensed images}

The GEE was used for creating a cloud-free composite image for five time periods (2000, 2005, 2010, 2015, and 2020) by utilizes imagery from Landsat-7, Landsat-8, and Sentinel-2 datasets. Methodology, as suggested by Zhu et al. (2015) was adopted for the extraction of composite images in an automated manner that incorporates a sophisticated cloud and shadow masking algorithm; an algorithm based on the spectral and thermal properties of clouds. It finds pixels that are bright and cold but do not share the spectral properties of snow. Further description can be referred to in the work done by Huang et al. (2010), Goodwin et al. (2013), Housman et al. (2015), and Tsai et al. (2018). 
The script for obtaining cloud-free image composite for the period 2000, 2005, 2015, and 2020 was implemented in GEE. The images were saved in Google drive and later downloaded from the drive for its manipulation and handling in ArcGIS and ERDAS EMAGINE software. The boundary indicating the extent of the study area was extracted from an existing topographic map sheet covering the area using ArcGIS software. Furthermore, the downloaded images were imported into ArcGIS software and utilized with the extracted boundary to define the area of interest (AOI) for each period.

The images of the defined AOI for each period were used to develop land cover maps for the years 2000, 2010, 2015, and 2020 in ERDAS software using supervised classification with the Maximum Likelihood Classifier. Dominant categories of land cover, viz., Built-up area, urban forest, water bodies, and open space were mapped (Table 1). A change matrix to see categorical changes of one land cover type in 2000 to another cover type in the years 2005, 2010, 2015, and 2020 was done using ERDAS. This thus provides an estimate of proportionate land cover changes from one category to another for five (5) years.

Table 1. Land cover classification scheme and their general description

\begin{tabular}{|c|c|}
\hline Classes & Description \\
\hline Built-up area & Residential, commercial, industrial, facilities and settlement \\
\hline Urban forest & $\begin{array}{r}\text { Evergreen forest and mixed forests with a higher density of trees; including mangrove, sparse } \\
\text { vegetation, etc. and all types of crops. }\end{array}$ \\
\hline Water bodies & Areas covered by water such as rivers, ponds, lagoons, dams, and waterlogged areas. \\
\hline Open space & Open land and non-vegetated land \\
\hline
\end{tabular}

\section{Extraction of human settlement extent using remotely sensed images}

The human settlement (HS) extent for each period (2000, 2005, 2010, 2015, and 2020) were extracted from Landsat data using GEE based on a processing chain referred to as spectral-based analysis (coupled with a spatial regularization) as suggested by Trianni et al. (2014). The approach for the extraction requires spatial and spectral processing. The processing chain consists of four steps; pre-processing and selection of the Landsat scene, computation of the Normalized Difference Spectral Vector (NDSV), classification, and spatial based post-processing. The graphical representation of the steps regarding the processing chain can be found in Figure 4.

Landsat 7 scene (for 2000, 2005, 2010) and Landsat 8 scene (for 2015 and 2020) were selected and scripts for creating variable representing a single image (for each scene) and for obtaining cloud-free images were implemented in GEE. The NDSV was used to detect urban area pixels from the obtained cloud-free images. Urban areas exhibit an NDSV spectral signature that is flat across all bands. Support Vector Machine (SVM) classifier was then utilized to characterize the HS. SVM classifier is a non-parametric classifier developed for hyperspectral data and able to manage high-dimensional spaces. Also, morphological operators aimed at getting rid of isolated pixels and at improving the homogeneity of the extracted settlements concerning their spatial distribution was applied as a post-processing step. Furthermore, the images of the extracted HS extent were exported and downloaded from Google drive for its manipulation and handling in ArcGIS software. The AOI shapefile and the downloaded images were used to define the extent of HS (for the year 2000, 2005, 2010, 2015, and 2020) within the study area. In addition, to further reveal the relationship between urban forest pattern of change and extent of HS pattern of change, the percentage change of urban forest and extent of HS in 2000-2005, 2005-2010, 2010-2015, and 2015-2020 were calculated.

\section{Results}

\section{Land cover pattern between 2000 and 2020}

The land cover (of the urban area of Ibadan city) mapped for the corresponding years of 2000, 2005, 2010, 2015, and 2020 is presented in Figure 5. Four prevailing categories of land cover identified in the study 
area are water bodies, built-up area, urban forest, and open space. A substantial change in the alteration of one land cover category into another was observed during the comparison years. The water bodies, urban forest, and open space classes noticeably decreased from $0.31 \%$ to $0.01 \%, 24.13 \%$ to $7.99 \%$, and $14.14 \%$ to $7.86 \%$ respectively while the built-up area class increased significantly from $61.42 \%$ to $84.14 \%$. The distribution of land cover within the urban area of Ibadan city during the years 2000, 2005, 2010, 2015, and 2020 is depicted in Table 2.

Water Bodies with the lowest land cover $(0.31 \%)$ in year 2000 , decreased to $0.22 \%, 0.18 \%, 0.13 \% .0 .01 \%$ in the year 2005, 2010, 2015 and 2020 respectively. Built-up area with the largest land cover (61.42\%) in the year 2000 , decreased to $53.51 \%$ in the year 2005 , then increased to $67.71 \%, 74.32 \%$, and $84.14 \%$ in the year 2010, 2015 and 2020 respectively. Furthermore, Urban forest with $24.13 \%$ land cover in the year 2000, decreased to $23.67 \%$ in the year 2005 but increased to $27.34 \%$ in the year 2010 , and then decreased to $18.46 \%$ and $7.99 \%$ in the year 2015 and 2020 respectively, while Open Space with $14.14 \%$ land cover in the year 2000, increased to $22.61 \%$ in the year 2005 , but decreased drastically to $4.77 \%$ in the year 2010 , and then increased to $7.09 \%$ and $7.86 \%$ in the year 2015 and 2020 respectively.
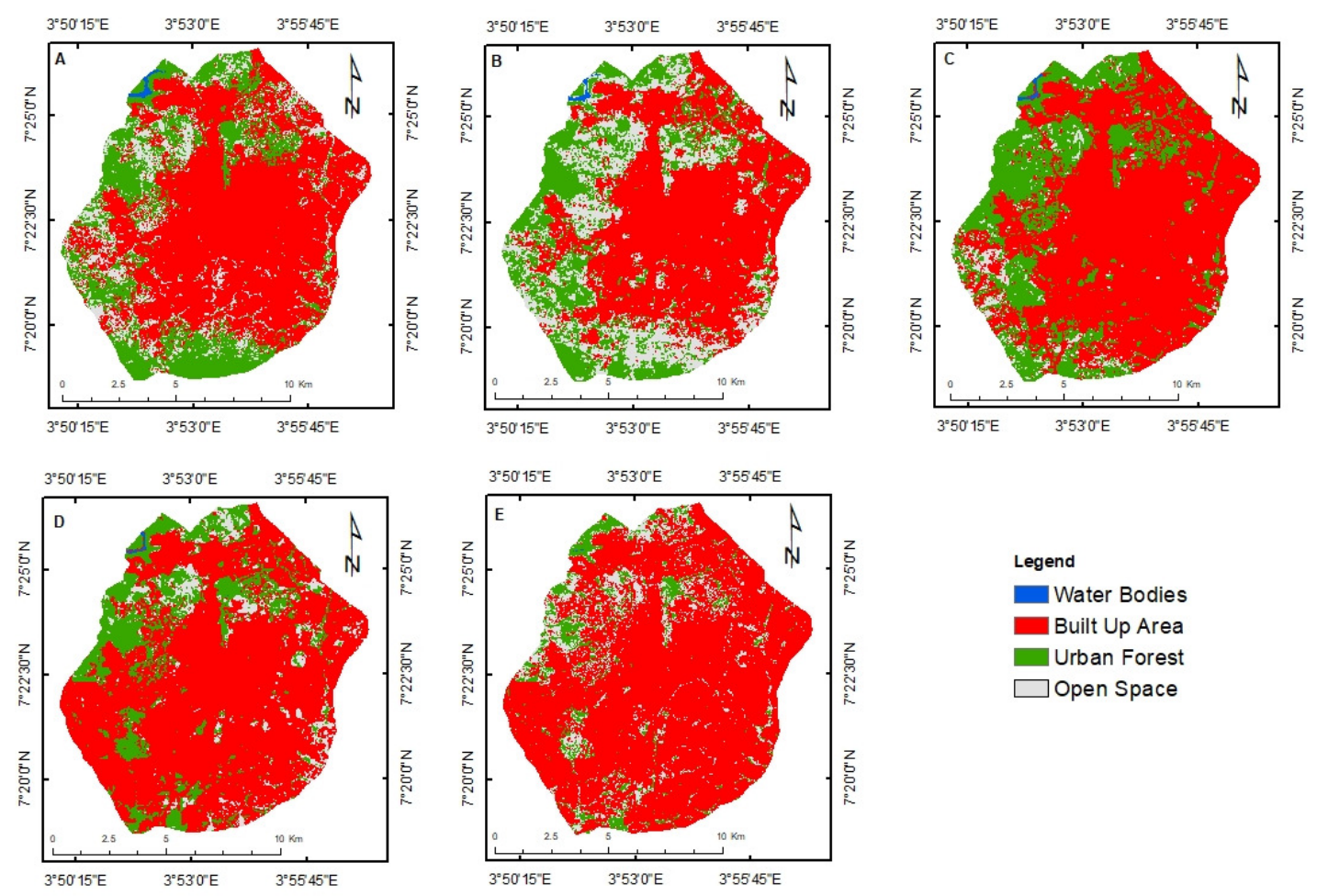

Figure 5. The land cover map of the urban area of Ibadan city, Nigeria: (a) year 2000; (b) year 2005; (c) year 2010 (d) year 2015 (e) year 2020 
Table 2. Land cover distribution of the urban area of Ibadan during the year 2000, 2005, 2010, 2015, and 2020

\begin{tabular}{|c|c|c|c|c|c|c|c|c|c|c|c|}
\hline \multirow{2}{*}{$\begin{array}{c}\text { Land } \\
\text { cover class }\end{array}$} & \multicolumn{2}{|c|}{2000} & \multicolumn{2}{|c|}{2005} & \multicolumn{2}{c|}{2010} & \multicolumn{2}{|c|}{2015} & \multicolumn{2}{|c|}{2020} & $\begin{array}{c}\text { Percentage } \\
\text { change }\end{array}$ \\
\cline { 2 - 12 } & $\mathrm{A}$ & $\mathrm{P}$ & $\mathrm{A}$ & $\mathrm{P}$ & $\mathrm{A}$ & $\mathrm{P}$ & $\mathrm{A}$ & $\mathrm{P}$ & $\mathrm{A}$ & $\mathrm{P}$ & $(2000-2020)$ \\
\cline { 2 - 12 } & $\left(\mathrm{Km}^{2}\right)$ & $(\%)$ & $\left(\mathrm{Km}^{2}\right)$ & $(\%)$ & $\left(\mathrm{Km}^{2}\right)$ & $(\%)$ & $\left(\mathrm{Km}^{2}\right)$ & $(\%)$ & $\left(\mathrm{Km}^{2}\right)$ & $(\%)$ & -95.65 \\
\hline $\begin{array}{c}\text { Water } \\
\text { bodies }\end{array}$ & 0.46 & 0.31 & 0.29 & 0.22 & 0.25 & 0.18 & 0.18 & 0.13 & 0.02 & 0.01 & +46.99 \\
\hline $\begin{array}{c}\text { Built up } \\
\text { area }\end{array}$ & 77.83 & 61.42 & 72.75 & 53.51 & 92.06 & 67.71 & 101.04 & 74.32 & 114.4 & 84.14 & +70.13 \\
\hline $\begin{array}{c}\text { Urban } \\
\text { forest }\end{array}$ & 36.36 & 24.13 & 32.18 & 23.67 & 37.17 & 27.34 & 25.1 & 18.46 & 10.86 & 7.99 & -79.88 \\
\hline $\begin{array}{c}\text { Open } \\
\text { space }\end{array}$ & 21.31 & 14.14 & 30.74 & 22.61 & 6.48 & 4.77 & 9.64 & 7.09 & 10.68 & 7.86 & -46 \\
\hline Total & 135.96 & 100 & 135.96 & 100 & 135.96 & 100 & 135.96 & 100 & 135.96 & 100 & \\
\hline
\end{tabular}

Note: Area (A) and Percentage (P)

Evaluation of urban forests cover under different human settlement extent between 2000 and 2020

The extent of HS within the urban area of Ibadan city generated for the corresponding years of 2000 , 2005, 2010, 2015, and 2020 is presented in Figure 6. A significant increase in the extent was detected during the comparison years. The extent of HS during the years 2000, 2005, 2010, 2015, and 2020 with their corresponding urban forest cover for the urban area of Ibadan is presented in Table 3 . The urban area of Ibadan had 24.14\% urban forest cover under 102,806 pixels of HS extent in the year 2000, 23.67\% urban forest cover under 80,833 pixels of HS extent in the year 2005, 27.34\% urban forest cover under 102,290 pixels of HS extent in the year 2010, 18.46\% urban forest cover under 112,271 pixels of HS extent in the year 2015, and $7.99 \%$ urban forest cover under 122,572 pixels of HS extent in the year 2020.

The pattern of change between urban forest cover and extent of HS at 5 years interval (2000-2005, 2005-2010, 2010-2015, and 2015-2020) for the urban area of Ibadan is presented in Figure 7. The pattern of changes in the urban forest and the extent of HS are both positive and negative. From 2000 to 2005, the negative change accounted for $1.91 \%$ and $21.37 \%$ in urban forest and extent of HS respectively; from 2005 to 2010, the positive change accounted for $15.50 \%$ and $26.54 \%$ in urban forest and extent of HS respectively; form 2010 to 2015, the negative change accounted for 32.48\% (in the urban forest) while the positive change accounted for $9.76 \%$ (in the extent of HS); and from 2015 to 2020, the negative change accounted for $56.72 \%$ (in the urban forest) while the positive change accounted for $9.18 \%$ (in the extent of HS).

Table 3. Urban forest and human settlement extent for the urban area of Ibadan during the year 2000, $2005,2010,2015$, and 2020

\begin{tabular}{|c|c|c|}
\hline Time period & Urban forest & Human settlement extent \\
\hline (Year) & $(\%)$ & (No of pixels) \\
\hline 2000 & 24.13 & 102806 \\
\hline 2005 & 23.67 & 80833 \\
\hline 2010 & 27.34 & 102290 \\
\hline 2015 & 18.46 & 112271 \\
\hline 2020 & 7.99 & 122572 \\
\hline
\end{tabular}



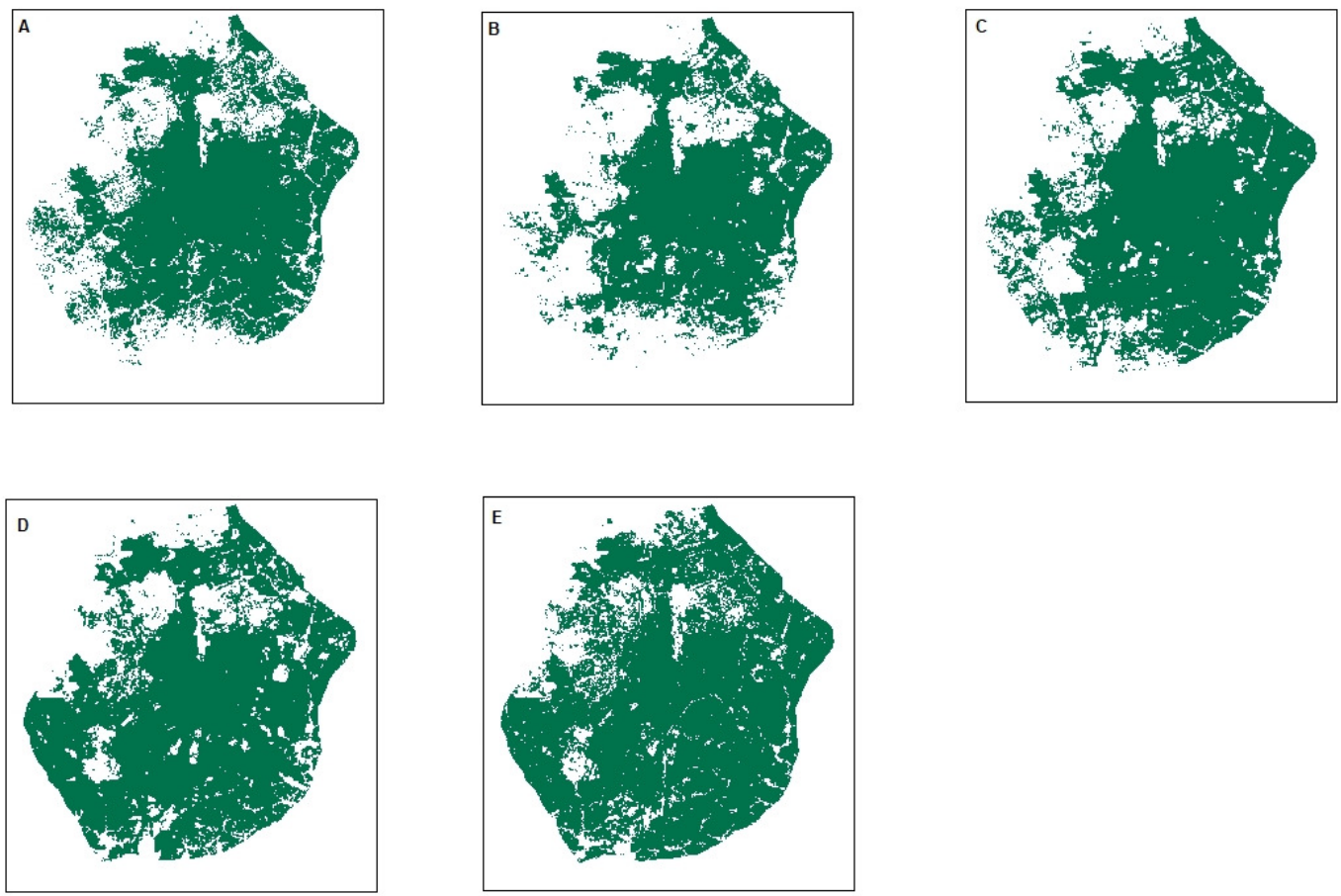

Figure 6. Reference GIS layer of human settlement extent extracted for the urban area of Ibadan city, Nigeria: (a) year 2000; (b) year 2005; (c) year 2010 (d) year 2015 (e) year 2020

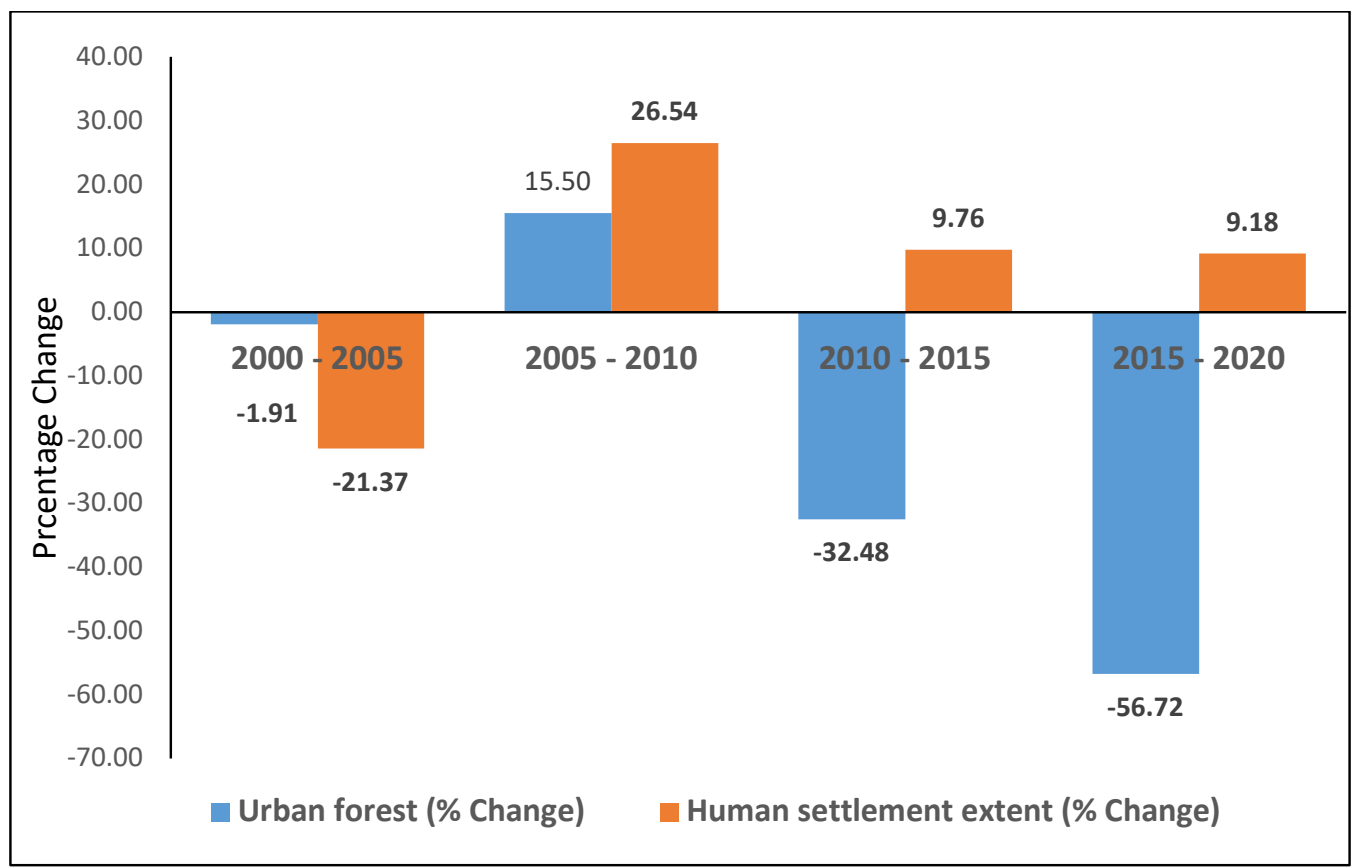

Figure 7. Pattern of change (in percentage) between urban forest and human settlement extent at 5 years interval for the urban area of Ibadan 


\section{Discussion}

The results revealed the past and current land cover patterns of the urban area of Ibadan city, HS extents, and urban forests cover under the influence of different HS extent. The water bodies, urban forest, and open space classes decreased while the built-up area class increased over twenty years. This implies a substantial redistribution of the landscape pattern. As reported by Asmat et al. (2012), and Noor and Rosni, (2013), a developing/growing city is usually characterized by a continuous restructuring of landscape pattern. The builtup area class decrease from $61.42 \%$ to $53.51 \%$ between the year 2000 and 2005 , but later continued to increase till the year 2020 with $84.14 \%$ (Table 2). The decrease between the years 2000 and 2005 is traceable to urban restructuring embarked upon by the then Oyo State government between the years 2004 and 2006 as reported by Akingbogun et al. (2012). Also, the changes can be largely attributed to anthropogenic activities such as urbanization activities (urban development and human settlement expansion, including road constructions, demolition, and construction of residential/non-residential buildings) and unstable government policy. According to Asmat et al. (2012), and Banai and DePriest, (2014), indicators of urbanization include not only the following, human settlement, land development, population, mix of residential and commercial land use, and multi-modal mobility options.

Furthermore, urban forest class decreased from $24.13 \%$ to $23.67 \%$ between the years 2000 and 2005 , increased to $27.34 \%$ in the year 2010, and then continued to decrease to $18.46 \%$ and $7.99 \%$ in the year 2015 and 2020 respectively (Table 2). The decrease between the year 2000 and 2005 implies the occurrence of forest destruction, which affirm the report of Popoola and Ajewole (2001), and Agbola et al. (2012) concerning the trends of urban forest deforestation and its consequences in Ibadan. The increase witnessed in the year 2010 can be linked to the impact of the afforestation program implemented within the city in the year 2006, as reported by Akingbogun et al. (2012). The observed continued decrease in the year 2015 and 2020, indicates major loss which could be attributed to rapid urbanization which has led to a massive conversion of vegetation/forested area to residential and non-residential areas. Several studies reported that swift urbanization has momentous impact causing many unforeseen consequences including loss of natural resources (such as forests), loss of prime farmland, increased environmental pollution, and many other physical, social and economic effect (Burchell and Shad, 1999; Sierra, 2001; Adelusi et al., 2002; Hasse and Lathrop, 2003; Noor and Rosni, 2013). Also, the decrease might have a great adverse influence on the quality of life within the city as reported by Popoola and Ajewole (2001). According to Kuchelmeister (2000), the conversion of forests and farmland for urban development can reduce water-permeable areas, upset natural drainage patterns, and cause serious flooding.

Also, HS extent increased from 102,806 to 122,572 pixels between the years 2000 and 2020 (Table 3). This suggests that the urban area of Ibadan city experienced urban expansion pointing to urbanization. Several studies agreed that urban expansion is an important indicator of urbanization (Nasser and Paul, 2001; Yeh and Xia, 2001; Weng, 2002; Sudhira et al., 2003; Jain, 2008; Ibrahim et al., 2009; Kulash, 2009; Li, 2009; Mohd Noor et al., 2012; ). Also, the urban forest cover was $24.14 \%$ under 102,806 pixels of HS extent in the year 2000, urban forest cover and HS extent decreased in the year 2005, both increased in the year 2010, however, in the year 2015 and 2020, urban forest cover decreased while HS extent increased (Table 3).

\section{Conclusions}

This research focused on examining the status of urban forests under the influence of different HS extents within the urban area of Ibadan city. The findings revealed considerable changes in landscape patterns within the urban area of Ibadan city for over twenty years (2000 - 2020). Furthermore, there is a significant decrease in the urban forests cover as a result of a substantial increase in HS extent. The study demonstrates the successful application of remote sensing and GIS tools for the acquisition of relevant information that can be 
used for mapping the status of urban forests cover and extents of HS within cities. The mapping is therefore important for proper, effective, and efficient landscape management. The study would be useful for urban forest managers and city planners who are involved in urban growth and green space development.

\section{Authors' Contributions}

Conceptualization: OS and AO; Data curation: OS; Formal analysis: OS; Investigation: OS, AO, and OO; Methodology: OS and AO; Project administration: AO and OO; Resources: OS, AO, and OO; 12

Software: OS; Supervision: AO and OO; Validation: OS, AO, and OO; Visualization: OS, AO, and OO; Writing - original draft: OS; Writing - review and editing: OS, AO, and OO. All authors read and approved the final manuscript.

\section{Acknowledgements}

We want to thank the Department of Forestry and Wildlife Management, Federal University of Agriculture, Abeokuta, Nigeria, and the Department of Forestry Technology, Federal College of Forestry, Ibadan, Nigeria for co-hosting this research and providing initial training.

\section{Conflict of Interests}

The authors declare that there are no conflicts of interest related to this article.

\section{References}

Adelusi HM, Agboola OD, Oni PI (2002). Urbanisation: implications for forest resources depletion and environmental degradation in Nigerian case study Ibadan city. In Forestry and challenges of sustainable livelihood. Proceedings of the 28th Annual Conference of the Forestry Association of Nigeria, Akure, Ondo State, Nigeria, 4-8 November, 2002 Forestry Association of Nigeria, pp 69-79.

Agbola BS, Ajayi O, Taiwo OJ, Wahab BW (2012). The August 2011 flood in Ibadan, Nigeria: Anthropogenic causes and consequences. International Journal of Disaster Risk Science 3(4):207-217. https://doi.org/10.1007/s13753012-0021-3

Akingbogun AA, Kosoko OS, Aborisade DK (2012). Remote sensing and GIS application for forest reserve degradation prediction and monitoring. In: First FIG young surveyors conference knowing to create the future. Rome pp 4-5.

Amanambu AC (2015). Geogenic contamination: Hydrogeochemical processes and relationships in shallow aquifers of Ibadan, South-West Nigeria. Bulletin of Geography. Physical Geography Series 9(1):5-20. https://doi.org/10.1515/bgeo-2015-0011

Zamzami SZ, Mansor S (2012). The use of multi-sensor for illegal human settlement detection. Asian Journal of Environment-Behaviour Studies 3(10):71-80. https://doi.org/10.21834/aje-bs.v3i7.270

Banai R, DePriest T (2010). Urban sprawl: Definitions, data, methods of measurement, and environmental consequences. Education 7.

Booth TH (1990). Mapping regions climatically suitable for particular tree species at the global scale. Forest Ecology and Management 36:47-60. https://doi.org/10.1016/0378-1127(90)90063-H

Burchell RW, Shad NA (1999). The incidence of sprawl in the United States. TCRP Report H 10, National Academy Press, Washington, D.C., The evolution of the sprawl debate in the United States. West. Northwest 5(2):137160. 
Booth TH, Stein JA, Nix HA, Hutchinson MF (1989). Mapping regions climatically suitable for particular species: an example using Africa. Forest Ecology and Management 28(1):19-31. https://doi.org/10.1016/03781127(89)90071-6

Chen R, Guinness RE (2014). Geospatial computing in mobile devices. Artech House pp 228.

Clark JR, Matheny NP, Cross G, Wade V (1997). A model of urban forestry sustainability. Journal of Arboriculture 23(1):17-30.

Gann SB (2003). A methodology for inventorying stored carbon in an urban forest. An unpublished paper submitted to the faculty of Virginia Polytechnic Institute and State University in partial fulfilment of the requirements of the degree of M.Sc Forestry.

Goodwin NR, Collett LJ, Denham RJ, Flood N, Tindall D (2013). Cloud and loud shadow screening across Queensland, Australia: An automated method for Landsat TM/ETM+ time series. Remote Sensing of Environment 134:5065. https://doi.org/10.1016/j.rse.2013.02.019

Gorelick N, Hancher M, Dixon M, Ilyushchenko S, Thau D, Moore R (2017). Google Earth Engine: Planetary-scale geospatial analysis for everyone. Remote Sensing of Environment 202:18-27. http://doi.org/10.1016/j.rse.2017.06.031

Hasse J, Lathrop GR (2003). A housing-unit-level approach to characterizing residential sprawl. Photogrammetric Engineering and Remote Sensing 69(9):1021-1030. https://doi.org/10.14358/PERS.69.9.1021

Housman I, Tanpipat V, Biswas T, Clark A, Stephen P, Maus P, Megown K (2015). Monitoring forest change in southeast Asia: case studies for USAID lowering emissions in Asia's forests (No. RSAC-10108-RPT1). Salt Lake City, UT: U.S. Department of Agriculture, Forest Service, Remote Sensing Applications Center pp 16.

Huang C, Thomas N, Goward SN, Masek JG, Zhu Z, Townshend JRG, Vogelmann JE (2010). Automated masking of cloud and cloud shadow for forest change analysis using Landsat images. International Journal of Remote Sensing 31(20):5449-5464. https://doi.org/10.1080/01431160903369642

bin Ibrahim AL, Sarvestani MS (2009). Urban sprawl pattern recognition using remote sensing and GIS -Case study Shiraz city, Iran. Joint Urban Remote Sensing Event, pp 1-5. http://dx.doi.org/10.1109/URS.2009.5137528

Jain M (2008). GIS and remote sensing applications to study urban sprawl of Udaipur, India. Research Scholar, Mohan LalSukhadia University, Udaipur, Raj., India.

Klemas VV (2001). Remote sensing of landscape level coastal environmental indicators Environmental Management 27:47-57. https://doi.org/10.1007/s002670010133

Kuchelmeister G (2000). Contributions and management of urban forestry in an increasingly urbanized world. Trees for the urban millennium: urban forestry update. Unasylva 200(51):49-55.

Kumar MS, Singh H, Pandey R, Singh MP, Ravindranath NH, Kalra N (2019). Assessing vulnerability of forest ecosystem in the Indian Western Himalayan region using trends of net primary productivity. Biodiversity and Conservation 28:2163-2182. https://doi.org/10.1007/s10531-018-1663-2

Larinde SL (2010). Practical issues in urban forest establishment and management. In: Ijeoma HM, Aiyeloja AA (Eds). Practical issues in forestry and wildlife resources management published by green canopy consultants. Choba, Port Harcourt pp 241-259.

Feng L (2009). Applying remote sensing and GIS on monitoring and measuring urban sprawl- a case study of China. Revista Internacional Sostenibilidad, Tecnología y Humanismo (4):47-56.

Lunetta P, Smith GS, Penttila A, Sajantila A (2004). Unintentional drowning in Finland 1970-2000: a population-based study. International Journal of Epidemiology 33:1053-1063. https://doi.org/10.1093/ije/dyh194

Masek JG, Lindsay FE, Goward SN (2000). Dynamics of urban growth in the Washington DC metropolitan area, $1973-$ 1996, from Landsat observations. International Journal of Remote Sensing 21(18:)3473-3486. https://doi.org/10.1080/014311600750037507

McPherson Gregory, Simpson JR (2001). Effects of California's urban forests on energy use and potential savings from large-scale tree plantings. Center for Urban Forest Research, Davis, CA. http://www.fs.fed.us

McPherson EG, Rowntree RA (2016). Energy conservation potential of urban tree planting. Journal of Arboriculture $19(6): 321-331$.

Mohd Noor N, Alias A, Mazlan H, Zainora MA (2012). Managing urban land in developing countries using GIS and remote sensing: towards resilient cities. Department of Urban and Regional Planning, IIUM, Gombak, Malaysia.

Nasser HE, Overberg P (2001). What you don't know about sprawl. US Today 22:6-9.

Noor NM, Rosni NA (2013). Determination of spatial factors in measuring urban sprawl in Kuantan using remote sensing and GIS. Procedia - Social and Behavioral Sciences 85:502-512. https://doi.org/10.1016/j.sbspro.2013.08.379 
Nowak DJ, Crane DE, Stevens JC (2007). Air pollution removal by urban trees and shrubs in the United States. Urban Forestry \& Urban Greening 4:115-123. https://doi.org/10.1016/j.ufug.2006.01.007

Nowak DJ, Noble MH, Sisinni SM, Dwyer JF (2001). People and trees: assessing the US urban forest resource. Journal of Forestry 99:37-42. https://doi.org/10.1093/jof/99.3.37

Olokeogun OS, Kumar M (2020). An indicator-based approach for assessing the vulnerability of riparian ecosystem under the influence of urbanization in the Indian Himalayan city, Dehradun. Ecological Indicators 119:106796. https://doi.org/10.1016/j.ecolind.2020.106796

Popoola L, Ajewole O (2001). Public perceptions of urban forests in Ibadan, Nigeria: implications for environmental conservation. Arboricultural Journal 25(1):122. https://doi.org/10.1080/03071375.2001.9747291

Savita PK, Sharma LK, Manoj K (2018). Forestry interventions for Ganga rejuvenation: a geospatial analysis for prioritizing sites. Indian Forester 144 (12):1127-1135.

Sierra Club (2001). Clearing the air with transit spending. http://www.sierraclub.org/sprawl/report01

Sudhira HS, Ramachandra TV, Jagadish KS (2003). Urban sprawl pattern recognition and modelling using GIS. Map India 28-31.

Tan KC, San Lim H, MatJafri MZ, Abdulla K (2010). Landsat data to evaluate urban expansion and determine land use/land cover changes in Penang Island, Malaysia. Environmental Earth Science 60:1509-1521. https://doi.org/10.1007/s12665-009-0286-Z

Trianni G, Angiuli E, Lisini G, Gamba P (2014). Human settlements from Landsat data using google earth engine. International Geoscience and Remote Sensing Symposium (IGARSS) 1473-1476. https://doi.org/10.1109/IGARSS.2014.6946715

Tsai YH, Stow D, Chen HL, Lewison R, An L, Shi L (2018). Mapping vegetation and land use types in Fanjingshan national nature reserve using google earth engine. Remote Sensing 10(6):927. https://doi.org/10.3390/rs10060927

Weng Q (2002). Land use change analysis in the Zhujiang Delta of China using satellite remote sensing, GIS and stochastic modelling. Journal of Environmental Management 64(3):273-284.

Wolf KL (2005a). Trees in the small city retail business district: Comparing resident and visitor perceptions. Journal of Forestry 103(8):390-395.

Wolf KL (2005b). Business district streetscapes, trees and consumer response. Journal of Forestry 103(8):396-400.

Wolf KL (2008). City trees, nature and physical activity: A research review. Arborist News 17(1):22-24.

Wood JP (1999). Tree Inventories and GIS in urban forestry. Project report submitted to the Faculty of the Virginia Polytechnic Institute and State University in partial fulfilment of the requirements for the degree of Master in Forestry, Blacksburg, Virginia.

Yeh AGO, Xia L (2001). Measurement and Monitoring of urban sprawl in a rapidly growing region using entropy. Photogrammetric Engineering \& Remote Sensing 67(1):83-90.

Zhu Z, Wang S, Woodcock CE (2015). Improvement and expansion of the Fmask algorithm: cloud, cloud shadow, and snow detection for Landsats 4-7, 8, and Sentinel 2 images. Remote Sensing of Environment 159:269-277. https://doi/org/10.1016/j.rse.2014.12.014

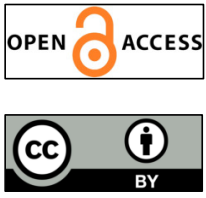

The journal offers free, immediate, and unrestricted access to peer-reviewed research and scholarly work. Users are allowed to read, download, copy, distribute, print, search, or link to the full texts of the articles, or use them for any other lawful purpose, without asking prior permission from the publisher or the author.

License - Articles published in Notulae Scientia Biologicae are Open-Access, distributed under the terms and conditions of the Creative Commons Attribution (CC BY 4.0) License.

(c) Articles by the authors; SHST, Cluj-Napoca, Romania. The journal allows the author(s) to hold the copyright/to retain publishing rights without restriction. 